\title{
Identification of serum microRNA profiles in colon cancer
}

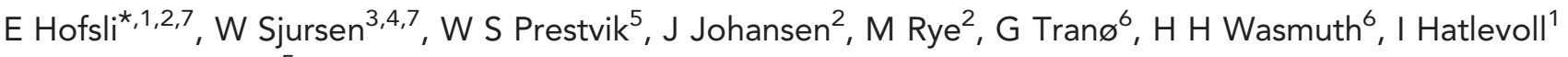 \\ and $L$ Thommesen ${ }^{5}$ \\ ${ }^{1}$ Department of Oncology, St Olavs Hospital, Trondheim University Hospital, Olav Kyrresgt 17, Trondheim 7006, Norway; ${ }^{2}$ Faculty \\ of Medicine, Department of Cancer and Molecular Medicine, Norwegian University of Science and Technology, Olav Kyrresgt 17, \\ Trondheim 7006, Norway; ${ }^{3}$ Department of Laboratory Medicine Children's and Women's Health, Norwegian University of Science \\ and Technology, Olav Kyrresgt 17, Trondheim 7006, Norway; ${ }^{4}$ Department of Pathology and Medical Genetics, St Olavs Hospital, \\ Trondheim University Hospital, Olav Kyrresgt 17, Trondheim 7006, Norway; ${ }^{5}$ Faculty of Technology, Sør-Trøndelag University \\ College, E.C. Dahlsgt 2, Trondheim 7004, Norway and ' Department of Gastrointestinal Surgery, St Olavs Hospital, Trondheim \\ University Hospital, Olav Kyrresgt 17, Trondheim 7006, Norway
}

Background: microRNAs (miRNAs) exist in blood in an apparently stable form. We have explored whether serum miRNAs can be used as non-invasive early biomarkers of colon cancer.

Methods: Serum samples from 30 patients with colon cancer stage IV and 10 healthy controls were examined for the expression of 375 cancer-relevant miRNAs. Based on the miRNA profile in this study, 34 selected miRNAs were measured in serum from 40 patients with stage I-II colon cancer and from 10 additional controls.

Results: Twenty miRNAs were differentially expressed in serum from stage IV patients compared with controls $(P<0.01)$. Unsupervised clustering revealed four subgroups; one corresponding mostly to the control group and the three others to the patient groups. Of the 34 miRNAs measured in the follow-up study of stage I-II patients, 21 showed concordant expression between stage IV and stage I-II patient. Based on the profiles of these 21 miRNAs, a supervised linear regression analysis (Partial Least Squares Regression) was performed. Using this model we correctly assigned stage I-II colon cancer patients based on miRNA profiles of stage IV patients.

Conclusion: Serum miRNA expression profiling may be utilised in early detection of colon cancer.

Colorectal cancer $(\mathrm{CRC})$ is the second leading cause of cancerrelated death in developed countries (Jemal et al, 2010; Hrasovec and Glavac, 2012). Early detection improves survival, as 5-year survival rate declines from nearly $90 \%$ in early-stage disease (stage I-II) to $12-13 \%$ in metastatic disease (stage IV; http://www. kreftregisteret.no). To detect early cancer or adenomas, various population-based screening programmes have been implemented (Geiger and Ricciardi, 2009; Hol et al, 2010). Colonoscopy is the gold standard method for early detection of CRC, but widespread use is limited due to its invasive nature and high costs. The most widely used non-invasive screening method, the fecal occult blood test, is compromised by limited diagnostic accuracy. Thus, new non-invasive methods are needed.

MicroRNAs (miRNAs) are small, 19-25 nucleotide noncoding RNAs, which negatively regulate gene transcription at transcriptional or post-transcriptional level (Iorio and Croce, 2012a) and have an important role in the control of biological processes, such as cellular development, differentiation, proliferation and apoptosis. Prior studies have demonstrated the impact of miRNAs in tumour biology and oncogenesis (Stefani and Slack, 2008; Inui

\footnotetext{
${ }^{\star}$ Correspondence: Dr E Hofsli, E-mail: eva.hofsli@stolav.no

${ }^{7}$ The first two authors are joint first authors.
}

Received 3 January 2013; revised 27 February 2013; accepted 28 February 2013; published online 4 April 2013 
et al, 2010; Babashah and Soleimani, 2011). MicroRNAs are frequently dysregulated in cancer and have shown great potential as tissue-based markers for cancer classification and prognostication (Paranjape et al, 2009; Gandellini et al, 2011; Kong et al, 2012; Iorio and Croce, 2012b).

In CRC tissue, various miRNAs have been found differentially expressed compared with matched normal tissue (Liu and Chen, 2010; Schee et al, 2010; Dong et al, 2011; Hrasovec and Glavac, 2012). Some miRNAs, as mir-21 (Schetter et al, 2008; Dong et al, 2011), miR-31 (Bandres et al, 2006; Dong et al, 2011) and miR-429 (Li et al, 2013), have been characterised as possible prognostic markers of CRC (Dong et al, 2011; Menendez et al, 2013), whereas others such as miR-126 (Hansen et al, 2012) and miR-150 (Ma et al, 2012) have been proposed as predictive markers of response to chemotherapy. Specific miRNA signatures have also been reported to predict response to neoadjuvant chemoradiotherapy in rectal cancer (Della Vittoria Scarpati et al, 2012; Kheirelseid et al, 2012).

MiRNAs are found in serum, plasma and other body fluids (Chen et al, 2008; Cortez et al, 2011), and exist in an apparently stable extracellular form (Zheng et al, 2011). The mechanism underlying their stability in the RNase-rich environment of blood is not well understood, but the current model posits that circulating miRNAs are stabilised by the formation of the Ago2miRNA complex and/or protected of degradation by encapsulation in exosomes (Valadi et al, 2007; Meckes et al, 2010; Zomer et al, 2010; Russo et al, 2012). Exosomes containing miRNA produced by malignant cells may have an important role in metastasis by promoting angiogenesis, cell proliferation and/or tumour cell invasion (Iorio and Croce, 2009; Liu et al, 2011; Zheng et al, 2011). The current comprehension involves that miRNA profiles in serum from cancer patients may mirror the profiles of the tumours. Several recent studies have characterised miRNA profiles in serum and urine aiming to identify appropriate diagnostic markers of cancer (Huang et al, 2010; Ohshima et al, 2010; Wittmann and Jack, 2010).

A limited number of studies have been undertaken searching for miRNA expression in blood from CRC patients (Chen et al, 2008; $\mathrm{Ng}$ et al, 2009; Huang et al, 2010; Pu et al, 2010; Nugent et al, 2012). The aim of this study was to identify miRNAs for early diagnosis of colon cancer. Serum samples from patients with newly diagnosed colon cancer and from blood donors were assessed for miRNA expression. We characterise a serum miRNA profile in colon cancer that may serve as a new non-invasive approach in early detection of colon cancer.

Patients and controls. Newly diagnosed colon cancer patients from two hospitals in Norway (St Olavs Hospital, Trondheim and Hamar Hospital, Hamar) were included, as described in Trano et al (2009). Blood, tumour tissue and adjacent normal mucosa were collected from the patients after informed consent had been obtained. The selected groups consisted of 30 patients with metastatic (stage IV) colon cancer, and 40 patients with early-stage colon cancer ( 7 patients with stage I and 33 with stage II). Serum from 20 blood donors aged $\geqslant 50$ years ( 10 females and 10 males) were used as controls (Blood bank, St Olavs Hospital, Trondheim).

MiRNA profiling by miRCURY LNA Universal RT miRNA PCR. Isolation of RNA and all real-time quantitative PCR (Q-PCR) experiments were performed by Exiqon Company, Vedbaek, Denmark (www.exiqon.com). RNA was purified from $250 \mu \mathrm{l}$ serum with the miRNeasy mini kit from Qiagen (Venlo, Holland) according to the manufacturers' protocol. Q-PCR was performed by using the miRCURY LNA Universal RT microRNA
PCR system containing 375 miRNA assays in Study 1, and 34 miRNAs in Study 2. In Study 1, there were no replicas, whereas in Study 2 three replicates per sample were polyadenylated and reverse transcribed (RT) into cDNA for all miRNA. One real-time Q-PCR amplification was performed for each RT reaction. Detectable miRNAs were those with a Cp (crossing point) $<37$, or $5 \mathrm{Cp}$ below the negative control.

Study design. Increasing numbers of studies postulate that colon and rectal cancer differ with respect to molecular and genetic characteristics (Li and Lai, 2009; Koga et al, 2010; Slattery et al, 2011). To ensure a homogenous patient population, only colonic cancer was included. Initially, we measured 375 cancer-relevant miRNAs in serum from 30 patients with stage IV disease and from 10 control samples (5 females and 5 males; Study 1). Twenty miRNAs were differentially expressed in serum from stage IV patients compared with controls $(P<0.01)$. Subsequently, serum from 40 patients with stage I-II colon cancer was analysed for the expression of 34 miRNAs (Study 2). In all, 20 of these miRNAs were selected based on differential expression in Study $1(P<0.01)$, 10 miRNAs were chosen from review of the miRNA literature and 4 miRNAs were additional reference miRNAs provided by Exiqon.

Statistical analysis. All miRNA profiles from Study 1 and Study 2 were normalised using the geometric mean for each sample over all miRNAs. Profiles of the 20 most differentially expressed miRNAs $(P<0.01)$ in Study 1 were subjected to hierarchical clustering to create a heatmap. Missing values were imputed using the K-nearest-neighbour method.

The 21 miRNAs that showed concordant expression in advanced (Study 1) and localised (Study 2) disease were used to construct a Partial Least Squares Regression (PLSR) model. The 21 miRNA profiles from Study 1 were used as model variables, and cancer status (1/-1 for cancer/control) for the 30 colon cancer patients and 10 controls in Study 1 was used as a target variable. Root-mean-square error after cross-validation indicated that two principal components were optimal for this model. The twocomponent PLSR model was then used to investigate whether the difference between cancer and control samples in Study 2 could be recognised using the miRNA profiles of the same 21 miRNAs used to create the model from Study 1. The profiles from Study 2 thus represent a completely independent test set for model evaluation. Results were displayed graphically to determine the optimal threshold separating cancers from controls. The analysis was performed using the statistical scripting language R (http://www. r-project.org/).

\section{RESULTS}

MiRNA profile in serum from patients with stage IV colon cancer. To investigate a possible difference in miRNA expression profile between colon cancer stage IV patients and healthy subjects, 375 cancer-relevant miRNAs were assessed in sera from 30 patients and 10 healthy blood donors (Study 1). Patients and tumour characteristics are shown in Table 1 . We observed a distinct different expression pattern in cancer $v s$ healthy subjects. Twenty miRNAs were significantly differentially expressed with $P<0.01$. A total of 9 miRNAs were upregulated and 11 downregulated. We performed a hierarchical clustering of the 20 miRNAs with highest differential expression between serum from patients and controls (Figure 1). This clustering analysis revealed four subgroups; one corresponding principally to the control group and the three others to the patient groups.

MicroRNA profile in serum from patients with stage I and II colon cancer. To examine whether a corresponding serum miRNA profile as demonstrated in colon cancer stage IV could 
Table 1. Patients' characteristics

\begin{tabular}{|l|c|c|}
\hline Characteristic & $\begin{array}{c}\text { Patients with } \\
\text { metastatic disease } \\
(\boldsymbol{n}=\mathbf{3 0}), \boldsymbol{n}(\%)\end{array}$ & $\begin{array}{c}\text { Patients with } \\
\text { localised disease } \\
(\boldsymbol{n}=\mathbf{4 0}), \boldsymbol{n}(\%)\end{array}$ \\
\hline Age (years) & $9(30)$ & $8(20)$ \\
\hline$<60$ & $8(26.7)$ & $12(30)$ \\
$60-75$ & $13(43.3)$ & $20(50)$ \\
$\geqslant 75$ & $68.6(41-86)$ & $72.4(30-93)$ \\
Median (range) & $14(46.7)$ & $18(45)$ \\
\hline Sex & $16(53.3)$ & $22(55)$ \\
\hline Male & \multicolumn{3}{|c|}{} \\
Female & $8(26.7)$ & $11(27.5)$ \\
\hline K-RAS mutation & $22(73.3)$ & $29(72.5)$ \\
\hline Yes &
\end{tabular}

B-RAF mutation

\begin{tabular}{|l|l|l|}
\hline Yes & $13(43.3)$ & $14(35)$ \\
No & $17(56.7)$ & $26(65)$ \\
\hline
\end{tabular}

Microsatellite instability

\begin{tabular}{|l|c|c|}
\hline Stable (MSS) & $23(76.7)$ & $15(37.5)$ \\
Unstable (MSI-H) & $7(23.3)$ & $25(62.5)$
\end{tabular}

\section{Tumour location}

\begin{tabular}{|l|c|c|}
\hline Coecum & $9(30)$ & $9(22.5)$ \\
Ascending colon & $4(13.3)$ & $8(20)$ \\
Right flexure & $0(0)$ & $4(10)$ \\
Transverse colon & $7(23.3)$ & $4(10)$ \\
Left flexure & $2(6.7)$ & $1(2.5)$ \\
Descending colon & $0(0)$ & $0(0)$ \\
Sigmoid colon & $8(26.7)$ & $14(35)$
\end{tabular}

\section{TNM status}

\begin{tabular}{l|c|c|} 
T1 & $0(0)$ & $3(7.5)$ \\
T2 & $1(3.3)$ & $4(10)$ \\
T3 & $19(63.3)$ & $28(70)$ \\
T4 & $9(30)$ & $5(12.5)$ \\
Missing & $1(3.3)$ & $0(0)$ \\
N0 & $8(26.7)$ & $40(100)$ \\
N1 & $7(23.3)$ & $0(0)$ \\
N2 & $15(50)$ & $0(0)$ \\
M0 & $0(0)$ & $40(100)$ \\
M1 & $30(100)$ & $0(0)$ \\
CEA & & \\
& & \\
$<5$ & $8(26.7)$ & \\
$5-100$ & $11(36.7)$ & $5(16.7)$ \\
$\geqslant 100$ & $6(20)$ & \\
Missing & \multicolumn{2}{|}{}
\end{tabular}

Abbreviations: $\mathrm{CEA}=$ carcinoembryonal antigen; $\mathrm{MSI}-\mathrm{Hi}=$ microsatellite instability-high; MSS = microsatellite stable; TNM $=$ TNM staging;

be found in early stage cancer, 34 miRNAs were further analysed in sera from 40 patients with stage I or II colon cancer and 10 healthy controls (Study 2). Figure 2 shows that 21 of the 26 detected miRNAs displayed the same expression profile as in advanced colon cancer, suggesting that most of these miRNAs are relevant as diagnostic markers. Of these 21 miRNAs, miR-423-5p, miR-210, miR-720, miR-320a and miR-378 showed the highest expression compared with controls, whereas miR-106a, miR-143, miR-103,
miR-199a-3p, miR-382 and miR-151-5p showed the lowest expression. The relevance to CRC of these 26 miRNAs according to literature is summarised in Table 2 .

The five miRNAs that showed different expression in early- $v s$ latestage cancer were miR-34a, miR-146a, miR-21, miR-484 and mir-425 (Figure 2). MiR-484 and miR-21 were highly expressed in stage IV as compared with controls, but lower expressed than controls in blood samples from early-stage I-II patients. The opposite was found for miR-34a and miR-146a. The expression level of miR-425 was reduced at stage I-II compared with controls, but no significant changes detected in samples from stage IV patients.

The PLSR model correctly assigns stage I-II colon cancer patients based on miRNA profiles of stage IV patients. We generally observed a good correspondence between expression profiles of stage IV (Study 1) and stage I-II cancer patients (Study 2), as 21 out of 26 miRNAs showed the same pattern of expression. This suggests that the miRNAs selected for analysis in Study 2 may be relevant as diagnostic markers. To investigate whether our miRNA expression profiles of stage IV colon cancer could be used to recognise cancer in early-stage I-II patients, we used PLSR, a supervised linear regression method, which is used for prediction and classification in multivariate analyses (Martens, 1989). Patient to patient variation in miRNA expression profiles makes it difficult to create reliable recognition models using individual miRNAs. Utilising information from several miRNA expression profiles simultaneously (multivariate analysis) is a powerful strategy to improve the confidence of such models. We thus used PLSR to model and validate our results. The model was trained using miRNA profiles from the 40 subjects (30 stage IV colon cancer patients and 10 controls) analysed in Study 1, and evaluated using cross-validation. The resulting model was then used to assign the 50 subjects (40 stage I-II cancer patients and 10 controls) from Study 2 to either the cancer or control group. In this setting, the subjects from Study 2 is regarded as a completely independent test set, and is not involved at any stage in the modelling phase. Partial Least Squares Regression can only assign independent data using the same set of miRNAs in the modelling and test set. We thus selected from Study 1 only the miRNAs assessed further in Study 2 to build our PLSR model. As five miRNAs showed clear inconsistencies in expression profiles between Study 1 and Study 2, these were not suited for modelling. The remaining set of 21 miRNAs was thus used in the final modelling and validation. The results are illustrated in Figure 3, showing that 9 out of 10 controls (specificity of $90 \%$ ) and 35 out of 40 cancer patients (sensitivity of $87.5 \%$ ) from Study 2 could be correctly assigned using the selected threshold.

\section{DISCUSSION}

In this study, we demonstrate distinct differences in the expression profile of miRNA in sera from colon cancer patients $v s$ healthy subjects, and identify a 21 miRNA serum colon cancer profile that may be utilised to identify colon cancer patients at an early stage of the disease. The generation of a PLSR model correctly assigned stage I-II patients based on the miRNA profiles of stage IV patients, which mathematically support the trend observed in our data.

The miRNA profile in sera from CRC patients did not show a uniform profile; but showed up to be clustered into three subgroups. These three subgroups may reflect the heterogeneity in gene expression and signalling pathways leading to CRC development. MicroRNA profiling may thus be a valuable supplement to the gene expression profiling of CRC subgroups.

Our demonstration of a difference in serum miRNA expression in colon cancer patients compared with healthy individuals are in 

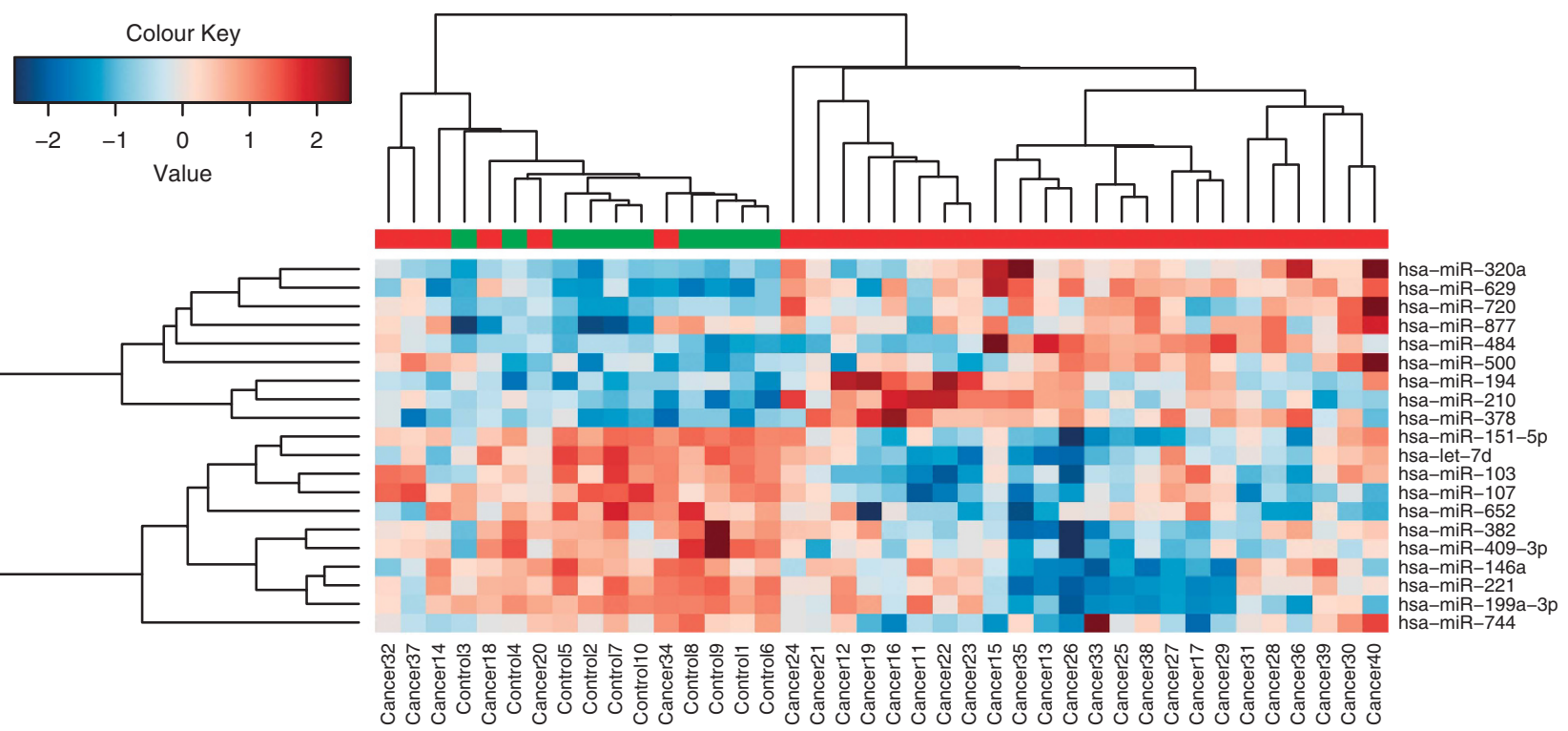

Figure 1. Heat-map diagram of a two-way hierarchical clustering analysis consisting of the 20 most differentially expressed miRNAs in serum from 30 metastatic (stage IV) colon cancer patients as compared with 10 healthy subjects $(P$-value $<0.01)$. Red colour represents an expression level above mean, blue colour represents expression lower than the mean. Upper colour labelling show patient samples in red and controls in green.

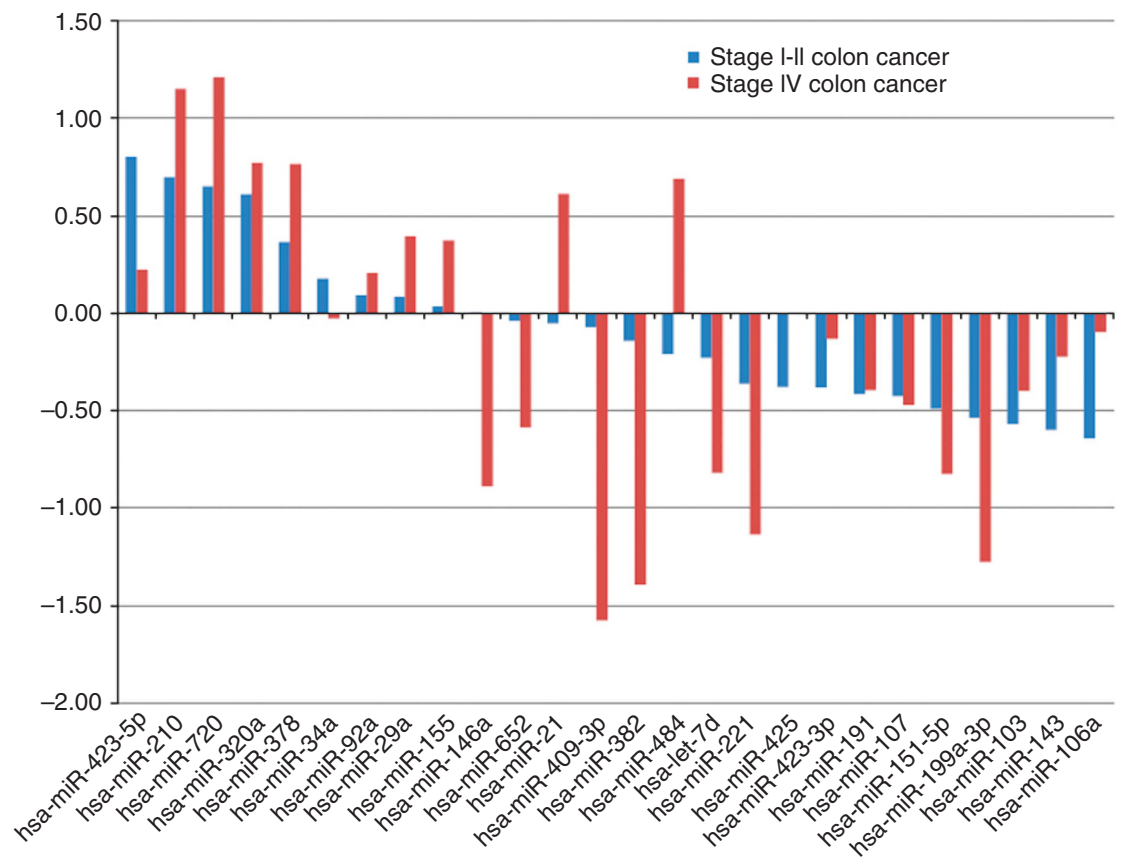

Figure 2. Differentially expressed miRNAs in stage IV (red bars) vs stage I-II (blue bars) colon cancer. The expression of 34 miRNAs was compared, and 26 miRNAs were detected. In all, 21 of 26 detected miRNAs showed the same expression profile in early-stage I-II vs metastatic stage IV colon cancer.

accordance with the relatively few studies that have assessed miRNA expression in serum of CRC patients (Chen et al, 2008; $\mathrm{Ng}$ et al, 2009; Huang et al, 2010; Pu et al, 2010; Nugent et al, 2012; Menendez et al, 2013). However, with regard to single miRNAs that have been reported differentially expressed, these studies present some conflicting results ( $\mathrm{Ng}$ et al, 2009; Huang et al, 2010; Cheng et al, 2011; Nugent et al, 2012). Our finding of an upregulation of miR-92a in sera from colon cancer patients is in accordance with studies by $\mathrm{Ng}$ et al (2009) and Huang et al (2010), but in contrast to studies by Cheng et al (2011) and Nugent et al (2012). The reasons for opposite results may be several. Whereas most studies have included both colon and rectal cancers in their analyses, our study involves only patients with colon cancer. Thus, the issue of possible differences in miRNA expression in colon $v s$ rectal cancer has been omitted in our study. Differential expression of miRNAs by tumour location could not be excluded (Slattery et al, 2011; Gaedcke et al, 2012), as well as ethnical differences in miRNA expression, which is reflected in studies from Norway (Cekaite et al, 2012) and China ( $\mathrm{Ng}$ et al, 2009; Huang et al, 2010). Moreover, the detection of miRNAs still involves challenges that are reflected both in the study design and the analytical methods. We therefore suggest that a serum miRNA 
Table 2. Examples of relevance to CRC of miRNAs found in sera from patients with metastatic (stage IV) and early stage (stage I-II) CRC

\begin{tabular}{|c|c|c|c|c|}
\hline microRNA & $\begin{array}{l}\text { Selection } \\
\text { criteria }\end{array}$ & $\begin{array}{l}\text { microRNA expression in CRC } \\
\text { compared with controls (literature) }\end{array}$ & $\begin{array}{l}\text { Concordance present study } \\
\text { and literature }\end{array}$ & References \\
\hline \multicolumn{5}{|c|}{ Upregulated in present study (stage I-II and IV colon cancer) } \\
\hline miR-423-5p & Reference & Not reported in CRC & New & \\
\hline miR-210 & $P<0.01$ & Upregulated (cells) & Yes & Ota et al (2012) \\
\hline miR-720 & $P<0.01$ & Upregulated (tissue) & Yes & $\begin{array}{l}\text { Ragusa et al (2012) } \\
\text { Della Vittoria Scarpati et al (2012) }\end{array}$ \\
\hline miR-320a & $P<0.01$ & Downregulated (tissue and cells) & No & $\begin{array}{l}\text { Schepeler et al (2008) } \\
\text { Sun et al (2012) }\end{array}$ \\
\hline miR-378 & $P<0.01$ & Downregulated (tissue) & No & Wang et al (2010); Faltejskova et al (2012) \\
\hline miR-92a & Literature & Upregulated (plasma) & Yes and no & Ng et al (2009) \\
\hline & & Downregulated (plasma) & & $\begin{array}{l}\text { Huang et al (2010) } \\
\text { Cheng et al (2011) }\end{array}$ \\
\hline miR-29a & Literature & Upregulated (plasma) & Yes & $\begin{array}{l}\text { Huang et al (2010); Weissmann-Brenner et al } \\
\text { (2012) }\end{array}$ \\
\hline miR-155 & Literature & Upregulated (tissue) & Yes & $\begin{array}{l}\text { Wang et al (2012) } \\
\text { Valeri et al (2010) }\end{array}$ \\
\hline \multicolumn{5}{|c|}{ Downregulated in present study (stage I-II and IV colon cancer) } \\
\hline miR-106a & Literature & Upregulated (stool) & No & $\begin{array}{l}\text { Link et al (2010) } \\
\text { Diaz et al (2008) }\end{array}$ \\
\hline miR-143 & Literature & Downregulated in CRC & Yes & Michael et al (2003) \\
\hline miR-103 & $P<0.01$ & Upregulated (cell lines and tissue) & No & $\begin{array}{l}\text { Gottardo et al (2007); Li et al (2011b); Chen } \\
\text { et al (2012) }\end{array}$ \\
\hline miR-199a-3p & $P<0.01$ & Not reported in CRC & New & \\
\hline miR-151-5p & $P<0.01$ & Not reported in CRC & New & \\
\hline miR-107 & $P<0.01$ & Upregulated (cell lines and tissue) & No & Chen et al (2012) \\
\hline miR-191 & Reference & Upregulated & No & Xi et al (2006) \\
\hline miR-423-3p & Reference & Not reported in CRC & New & \\
\hline miR221 & $P<0.01$ & Upregulated (blood) & No & Pu et al (2010) \\
\hline miR-let7d & $P<0.01$ & Not reported in CRC & New & \\
\hline miR-382 & $P<0.01$ & Downregulated & New & \\
\hline miR-409-3p & $P<0.01$ & Not reported in CRC & New & \\
\hline miR-652 & $P<0.01$ & Upregulated (rectal cancer) & No & $\begin{array}{l}\text { Lulla et al (2011) } \\
\text { Gao et al (2011) }\end{array}$ \\
\hline
\end{tabular}

Different expression in the present study between stage I-II and IV colon cancer

\begin{tabular}{|c|c|c|c|c|}
\hline miR-34a & Literature & Upregulated & $\begin{array}{l}\text { Yes (present study: upreg stage I-II; } \\
\text { weak downreg stage IV) }\end{array}$ & Wang et al (2012) \\
\hline & & Downregulated (serum) & & Nugent et al (2012) \\
\hline miR-146a & $P<0.01$ & No difference (serum) & No (present study: downreg stage IV) & Huang et al (2010) \\
\hline miR-21 & Literature & Upregulated (tissue and blood) & $\begin{array}{l}\text { Yes (present study: upreg stage IV; } \\
\text { weak downreg stage I-II) }\end{array}$ & $\begin{array}{l}\text { Schetter et al (2008); Pu et al (2010); Dong } \\
\text { et al (2011); Kanaan et al (2012) }\end{array}$ \\
\hline miR-484 & $P<0.01$ & Not reported in CRC & New & \\
\hline miR-425 & Reference & No difference (tissue) & No (present study: downreg stage I-II) & Chang et al (2010) \\
\hline
\end{tabular}

profile may be more reliable than the detection of few individual miRNAs.

Several of the 21 miRNAs that constitute our colon cancer serum miRNA profile have been described to be involved in the development of cancer. Our demonstration of an enhanced expression of miR-21 is in accordance with previous reports showing elevated levels of miR-21 both in CRC tissue (Schetter et al, 2008; Dong et al, 2011) and blood (Pu et al, 2010; Kanaan et al, 2012). In a recent systematic review, overexpression of miR21 and a reduced expression of let-7d were the two miRNAs that most frequently were associated with poor outcome across diverse malignancies (Nair et al, 2012). Interestingly, a recent large study from Denmark characterised the mir-21 expression as a prognostic factor in stage II colon cancer (Kjaer-Frifeldt et al, 2012). Members of the Let-7 family are reduced in a wide range of cancers and target-known oncogenes, like c-myc, RAS and HMGA2, and are therefore considered as to function as tumour suppressor-like miRNAs (Menendez et al, 2013). Our demonstration of a reduced level of miR-let-7d in sera from colon cancer patients was therefore not surprisingly, but to our knowledge, no previous assessment of 


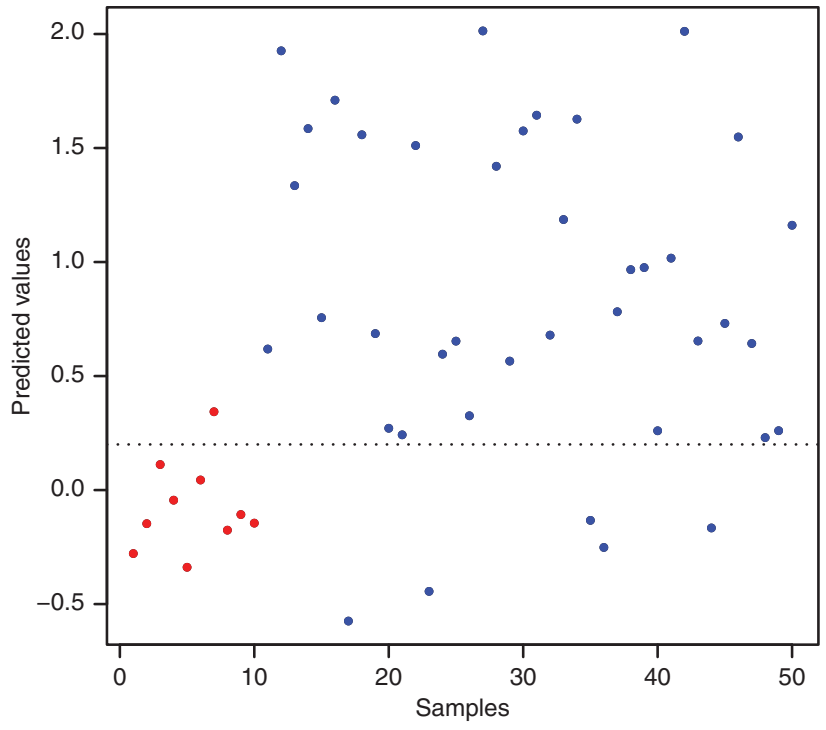

Figure 3. Prediction analysis of early-stage colon cancer patients. Controls are shown in red and cancer samples in blue. 9 out of 10 healthy controls were correctly predicted as true negatives and 35 out of 40 patients with cancer as true positives.

let-7d expression in sera from colon cancer patients has been reported. MiR-378 has been shown to function as an oncogene-like miRNA (Lee et al, 2007), to be functionally important for c-Mycdriven transformation (Feng et al, 2011) and to correlate with progression of human breast cancer (Eichner et al, 2010). However, in other studies, miR-378 has been found to be downregulated in CRC tissue (Wang et al, 2010; Faltejskova et al, 2012). In accordance with our results, a higher expression of miR-720 has been demonstrated in CRC tissue than in normal colon epithelial tissue controls (Ragusa et al, 2012).

Perhaps, somewhat unexpected was our findings of reduced serum levels of miR-103 and miR-107 in colon cancer patients compared with controls. MiR-103 and miR-107 have been found highly expressed in several solid tumours (Gottardo et al, 2007; Li et al, 2011b; Kim et al, 2012), and have been associated with poor prognosis in CRC. (Chen et al, 2012). On the other hand, a downregulation of miR-103 has been found in haematological malignancies (Li et al, 2011a; Machova Polakova et al, 2011). Notably, the miR-103/107 family is located to chromosomal loci prone to deletions or amplifications, and miR-103/107 is consequently reported to be deregulated in various diseases (Finnerty et al, 2010). We cannot exclude that the decreased miRNA expression found in our study reflects such genomic alterations. In our opinion, the diagnostic value of these miRNAs in blood should thus be evaluated with caution and at least compared with genomic analysis of the tumour sample.

Although our results have to be confirmed in larger clinical studies, the identification of a miRNA profile in serum of earlystage colon cancer patient that is quite similar to the late-stage cancer patients is promising and suggests that the miRNA profile may be used to identify early-stage cancer. Taken into consideration the complex regulation of miRNAs, we advocate that the miRNA profile - rather than assessment of a single miRNA expression - must be the foundation in establishing potentially new biomarkers.

In conclusion, we have identified a 21 miRNA profile in blood samples from colon cancer patients consisting of miRNAs that have been previously reported as possible markers of CRC, others not. Our study identifying miRNA expression profiles indicates that serum miRNA may be utilised to detect colon cancer in early curative stages.

\section{REFERENCES}

Babashah S, Soleimani M (2011) The oncogenic and tumour suppressive roles of microRNAs in cancer and apoptosis. Eur J Cancer 47(8): 1127-1137.

Bandres E, Cubedo E, Agirre X, Malumbres R, Zarate R, Ramirez N, Abajo A, Navarro A, Moreno I, Monzo M, Garcia-Foncillas J (2006) Identification by Real-time PCR of 13 mature microRNAs differentially expressed in colorectal cancer and non-tumoral tissues. Mol Cancer 5: 29.

Cancer Genome Atlas Network (2012) Comprehensive molecular characterization of human colon and rectal cancer. Nature 487(7407): 330-337.

Cekaite L, Rantala JK, Bruun J, Guriby M, Agesen TH, Danielsen SA, Lind GE, Nesbakken A, Kallioniemi O, Lothe RA, Skotheim RI (2012) MiR-9, -31, and -182 deregulation promote proliferation and tumor cell survival in colon cancer. Neoplasia. (New York, NY) 14(9): 868-881.

Chang KH, Mestdagh P, Vandesompele J, Kerin MJ, Miller N (2010) MicroRNA expression profiling to identify and validate reference genes for relative quantification in colorectal cancer. BMC Cancer 10: 173.

Chen HY, Lin YM, Chung HC, Lang YD, Lin CJ, Huang J, Wang WC, Lin FM, Chen Z, Huang HD, Shyy JY, Liang JT, Chen RH (2012) miR-103/107 promote metastasis of colorectal cancer by targeting the metastasis suppressors DAPK and KLF4. Cancer Res 72(14): 3631-3641.

Chen X, Ba Y, Ma L, Cai X, Yin Y, Wang K, Guo J, Zhang Y, Chen J, Guo X, Li Q, Li X, Wang W, Wang J, Jiang X, Xiang Y, Xu C, Zheng P, Zhang J, Li R, Zhang H, Shang X, Gong T, Ning G, Zen K, Zhang CY (2008)

Characterization of microRNAs in serum: a novel class of biomarkers for diagnosis of cancer and other diseases. Cell Res 18(10): 997-1006.

Cheng H, Zhang L, Cogdell DE, Zheng H, Schetter AJ, Nykter M, Harris CC, Chen K, Hamilton SR, Zhang W (2011) Circulating plasma MiR-141 is a novel biomarker for metastatic colon cancer and predicts poor prognosis. PLoS One 6(3): e17745.

Cortez MA, Bueso-Ramos C, Ferdin J, Lopez-Berestein G, Sood AK, Calin GA (2011) MicroRNAs in body fluids-the mix of hormones and biomarkers. Nat Rev Clin Oncol 8(8): 467-477.

Della Vittoria Scarpati G, Falcetta F, Carlomagno C, Ubezio P, Marchini S, De Stefano A, Singh VK, D'Incalci M, De Placido S, Pepe S (2012) A specific miRNA signature correlates with complete pathological response to neoadjuvant chemoradiotherapy in locally advanced rectal cancer. Int $J$ Rad Oncol Biol Phys 83(4): 1113-1119.

Diaz R, Silva J, Garcia JM, Lorenzo Y, Garcia V, Pena C, Rodriguez R, Munoz C, Garcia F, Bonilla F, Dominguez G (2008) Deregulated expression of miR-106a predicts survival in human colon cancer patients. Genes Chromosomes Cancer 47(9): 794-802.

Dong Y, Wu WK, Wu CW, Sung JJ, Yu J, Ng SS (2011) MicroRNA dysregulation in colorectal cancer: a clinical perspective. $\mathrm{Br} J$ Cancer 104(6): 893-898.

Eichner LJ, Perry MC, Dufour CR, Bertos N, Park M, St-Pierre J, Giguere V (2010) miR-378( ${ }^{*}$ ) mediates metabolic shift in breast cancer cells via the PGC-1beta/ERRgamma transcriptional pathway. Cell Metab 12(4): 352-361.

Faltejskova P, Svoboda M, Srutova K, Mlcochova J, Besse A, Nekvindova J, Radova L, Fabian P, Slaba K, Kiss I, Vyzula R, Slaby O (2012) Identification and functional screening of microRNAs highly deregulated in colorectal cancer. J Cell Mol Med 16(11): 2655-2666.

Feng M, Li Z, Aau M, Wong CH, Yang X, Yu Q (2011) Myc/miR-378/TOB2/ cyclin D1 functional module regulates oncogenic transformation. Oncogene 30(19): 2242-2251.

Finnerty JR, Wang WX, Hebert SS, Wilfred BR, Mao G, Nelson PT (2010) The miR-15/107 group of microRNA genes: evolutionary biology, cellular functions, and roles in human diseases. J Mol Biol 402(3): 491-509.

Gaedcke J, Grade M, Camps J, Sokilde R, Kaczkowski B, Schetter AJ, Difilippantonio MJ, Harris CC, Ghadimi BM, Moller S, Beissbarth T, Ried T, Litman T (2012) The rectal cancer microRNAome-microRNA expression in rectal cancer and matched normal mucosa. Clin Cancer Res 18(18): 4919-4930.

Gandellini P, Profumo V, Folini M, Zaffaroni N (2011) MicroRNAs as new therapeutic targets and tools in cancer. Exp Opin Ther Targets 15(3): 265-279.

Gao W, Shen H, Liu L, Xu J, Shu Y (2011) MiR-21 overexpression in human primary squamous cell lung carcinoma is associated with poor patient prognosis. J Cancer Res Clin Oncol 137(4): 557-566.

Geiger TM, Ricciardi R (2009) Screening options and recommendations for colorectal cancer. Clin Colon Rectal Surg 22(4): 209-217. 
Gottardo F, Liu CG, Ferracin M, Calin GA, Fassan M, Bassi P, Sevignani C, Byrne D, Negrini M, Pagano F, Gomella LG, Croce CM, Baffa R (2007) Micro-RNA profiling in kidney and bladder cancers. Urol Oncol 25(5): 387-392.

Hansen TF, Sorensen FB, Lindebjerg J, Jakobsen A (2012) The predictive value of microRNA-126 in relation to first line treatment with capecitabine and oxaliplatin in patients with metastatic colorectal cancer. BMC Cancer 12: 83.

Hol L, de Jonge V, van Leerdam ME, van Ballegooijen M, Looman CW, van Vuuren AJ, Reijerink JC, Habbema JD, Essink-Bot ML, Kuipers EJ (2010) Screening for colorectal cancer: comparison of perceived test burden of guaiac-based faecal occult blood test, faecal immunochemical test and flexible sigmoidoscopy. Eur J Cancer 46(11): 2059-2066.

Hrasovec S, Glavac D (2012) MicroRNAs as novel biomarkers in colorectal cancer. Front Genet 3: 180.

Huang Z, Huang D, Ni S, Peng Z, Sheng W, Du X (2010) Plasma microRNAs are promising novel biomarkers for early detection of colorectal cancer. Int J Cancer 127(1): 118-126.

Inui M, Martello G, Piccolo S (2010) MicroRNA control of signal transduction. Nat Rev Mol Cell Biol 114: 252-263.

Iorio MV, Croce CM (2009) MicroRNAs in cancer: small molecules with a huge impact. J Clin Oncol 27(34): 5848-5856.

Iorio MV, Croce CM (2012a) MicroRNA dysregulation in cancer: diagnostics, monitoring and therapeutics. A comprehensive review. EMBO Mol Med 4(3): 143-159.

Iorio MV, Croce CM (2012b) microRNA involvement in human cancer. Carcinogenesis 33(6): 1126-1133.

Jemal A, Siegel R, Xu J, Ward E (2010) Cancer statistics, 2010. CA: a Cancer J Clin 60(5): 277-300.

Kanaan Z, Rai SN, Eichenberger MR, Roberts H, Keskey B, Pan J, Galandiuk S (2012) Plasma miR-21: a potential diagnostic marker of colorectal cancer. Ann Surg 256(3): 544-551.

Kheirelseid EA, Miller N, Chang KH, Curran C, Hennessey E, Sheehan M, Newell J, Lemetre C, Balls G, Kerin MJ (2012) miRNA expressions in rectal cancer as predictors of response to neoadjuvant chemoradiation therapy. Int J Colorectal Dis 18: 18.

Kim BH, Hong SW, Kim A, Choi SH, Yoon SO (2012) Prognostic implications for high expression of oncogenic microRNAs in advanced gastric carcinoma. J Surg Oncol 20(10): 23271.

Kjaer-Frifeldt S, Hansen TF, Nielsen BS, Joergensen S, Lindebjerg J, Soerensen FB, Depont Christensen R, Jakobsen A (2012) The prognostic importance of miR-21 in stage II colon cancer: a population-based study. Br J Cancer 107(7): 1169-1174.

Koga Y, Yasunaga M, Takahashi A, Kuroda J, Moriya Y, Akasu T, Fujita S, Yamamoto S, Baba H, Matsumura Y (2010) MicroRNA expression profiling of exfoliated colonocytes isolated from feces for colorectal cancer screening. Cancer Prev Res 3(11): 1435-1442.

Kong YW, Ferland-McCollough D, Jackson TJ, Bushell M (2012) microRNAs in cancer management. Lancet Oncol 13(6): e249-e258.

Lee DY, Deng Z, Wang CH, Yang BB (2007) MicroRNA-378 promotes cell survival, tumor growth, and angiogenesis by targeting SuFu and Fus-1 expression. Proc Natl Acad Sci USA 104(51): 20350-20355.

Li FY, Lai MD (2009) Colorectal cancer, one entity or three. J Zhejiang Univ Sci B 10(3): 219-229.

Li J, Du L, Yang Y, Wang C, Liu H, Wang L, Zhang X, Li W, Zheng G, Dong Z (2013) MiR-429 Is an Independent Prognostic Factor in Colorectal Cancer and Exerts Its Anti-apoptotic Function by Targeting SOX2. Cancer Lett 329(1): 84-90.

Li S, Moffett HF, Lu J, Werner L, Zhang H, Ritz J, Neuberg D, Wucherpfennig KW, Brown JR, Novina CD (2011a) MicroRNA expression profiling identifies activated B cell status in chronic lymphocytic leukemia cells. PLoS One 6(3): e16956.

Li X, Zhang Y, Zhang H, Liu X, Gong T, Li M, Sun L, Ji G, Shi Y, Han Z, Han S, Nie Y, Chen X, Zhao Q, Ding J, Wu K, Daiming F (2011b) miRNA-223 promotes gastric cancer invasion and metastasis by targeting tumor suppressor EPB41L3. Mol Cancer Res 9(7): 824-833.

Link A, Balaguer F, Shen Y, Nagasaka T, Lozano JJ, Boland CR, Goel A (2010) Fecal MicroRNAs as novel biomarkers for colon cancer screening. Cancer Epidemiol Biomarkers Prev 19(7): 1766-1774.

Liu F, Lou YL, Wu J, Ruan QF, Xie A, Guo F, Cui SP, Deng ZF, Wang Y (2011) Upregulation of MicroRNA-210 regulates renal angiogenesis mediated by activation of VEGF signaling pathway under ischemia/ perfusion injury in vivo and in vitro. Kidney Blood Press Res 35(3): 182-191.
Liu M, Chen H (2010) The role of microRNAs in colorectal cancer. J Genet Genomics 37(6): 347-358.

Lulla RR, Costa FF, Bischof JM, Chou PM, de F Bonaldo M, Vanin EF, Soares MB (2011) Identification of differentially expressed microRNAs in osteosarcoma. Sarcoma 2011: 732690.

Ma Y, Zhang P, Wang F, Zhang H, Yang J, Peng J, Liu W, Qin H (2012) miR150 as a potential biomarker associated with prognosis and therapeutic outcome in colorectal cancer. Gut 61(10): 1447-1453.

Machova Polakova K, Lopotova T, Klamova H, Burda P, Trneny M, Stopka T, Moravcova J (2011) Expression patterns of microRNAs associated with CML phases and their disease related targets. Mol Cancer 10: 41.

Martens HNT (1989) Multivariate Calibration ChichesterWiley.

Meckes Jr. DG, Shair KH, Marquitz AR, Kung CP, Edwards RH, Raab-Traub N (2010) Human tumor virus utilizes exosomes for intercellular communication. Proc Natl Acad Sci USA 107(47): 20370-20375.

Menendez P, Villarejo P, Padilla D, Menendez JM, Montes JA (2013) Diagnostic and prognostic significance of serum MicroRNAs in colorectal cancer. J Surg Oncol 107(2): 217-220.

Michael MZ, O’ Connor SM, van Holst Pellekaan NG, Young GP, James RJ (2003) Reduced accumulation of specific microRNAs in colorectal neoplasia. Mol Cancer Res 1(12): 882-891.

Nair VS, Maeda LS, Ioannidis JP (2012) Clinical outcome prediction by microRNAs in human cancer: a systematic review. J Natl Cancer Inst 104(7): 528-540.

Ng EK, Chong WW, Jin H, Lam EK, Shin VY, Yu J, Poon TC, Ng SS, Sung JJ (2009) Differential expression of microRNAs in plasma of patients with colorectal cancer: a potential marker for colorectal cancer screening. Gut 58(10): 1375-1381.

Nugent M, Miller N, Kerin MJ (2012) Circulating miR-34a levels are reduced in colorectal cancer. J Surg Oncol 106(8): 947-952.

Ohshima K, Inoue K, Fujiwara A, Hatakeyama K, Kanto K, Watanabe Y, Muramatsu K, Fukuda Y, Ogura S, Yamaguchi K, Mochizuki T (2010) Let-7 microRNA family is selectively secreted into the extracellular environment via exosomes in a metastatic gastric cancer cell line. PLoS One 5(10): e13247.

Ota T, Doi K, Fujimoto T, Tanaka Y, Ogawa M, Matsuzaki H, Kuroki M, Miyamoto S, Shirasawa S, Tsunoda T (2012) KRAS up-regulates the expression of miR-181a, miR-200c and miR-210 in a three-dimensionalspecific manner in DLD-1 colorectal cancer cells. Anticancer Res 32(6): 2271-2275.

Paranjape T, Slack FJ, Weidhaas JB (2009) MicroRNAs: tools for cancer diagnostics. Gut 58(11): 1546-1554.

Pu XX, Huang GL, Guo HQ, Guo CC, Li H, Ye S, Ling S, Jiang L, Tian Y, Lin TY (2010) Circulating miR-221 directly amplified from plasma is a potential diagnostic and prognostic marker of colorectal cancer and is correlated with p53 expression. J Gastroenterol Hepatol 25(10): 1674-1680.

Ragusa M, Statello L, Maugeri M, Majorana A, Barbagallo D, Salito L, Sammito M, Santonocito M, Angelica R, Cavallaro A, Scalia M, Caltabiano R, Privitera G, Biondi A, Di Vita M, Cappellani A, Vasquez E, Lanzafame S, Tendi E, Celeste S, Di Pietro C, Basile F, Purrello M (2012) Specific alterations of the microRNA transcriptome and global network structure in colorectal cancer after treatment with MAPK/ERK inhibitors. $J \mathrm{Mol}$ Med 4: 4.

Russo F, Di Bella S, Nigita G, Macca V, Lagana A, Giugno R, Pulvirenti A, Ferro A (2012) miRandola: Extracellular Circulating MicroRNAs Database. PLoS One 7(10): e47786.

Schee K, Fodstad O, Flatmark K (2010) MicroRNAs as biomarkers in colorectal cancer. Am J Pathol 177(4): 1592-1599.

Schepeler T, Reinert JT, Ostenfeld MS, Christensen LL, Silahtaroglu AN, Dyrskjot L, Wiuf C, Sorensen FJ, Kruhoffer M, Laurberg S, Kauppinen S, Orntoft TF, Andersen CL (2008) Diagnostic and prognostic microRNAs in stage II colon cancer. Cancer Res 68(15): 6416-6424.

Schetter AJ, Leung SY, Sohn JJ, Zanetti KA, Bowman ED, Yanaihara N, Yuen ST, Chan TL, Kwong DL, Au GK, Liu CG, Calin GA, Croce CM, Harris CC (2008) MicroRNA expression profiles associated with prognosis and therapeutic outcome in colon adenocarcinoma. JAMA 299(4): 425-436.

Slattery ML, Wolff E, Hoffman MD, Pellatt DF, Milash B, Wolff RK (2011) MicroRNAs and colon and rectal cancer: differential expression by tumor location and subtype. Genes Chromosomes Cancer 50(3): 196-206.

Stefani G, Slack FJ (2008) Small non-coding RNAs in animal development. Nat Rev Mol Cell Biol 9(3): 219-230.

Sun JY, Huang Y, Li JP, Zhang X, Wang L, Meng YL, Yan B, Bian YQ, Zhao J, Wang WZ, Yang AG, Zhang R (2012) MicroRNA-320a suppresses human 
colon cancer cell proliferation by directly targeting beta-catenin. Biochem Biophys Res Commun 420(4): 787-792.

Trano G, Wasmuth HH, Sjursen W, Hofsli E, Vatten LJ (2009) Awareness of heredity in colorectal cancer patients is insufficient among clinicians: a Norwegian population-based study. Colorectal Dis 11(5): 456-461.

Valadi H, Ekstrom K, Bossios A, Sjostrand M, Lee JJ, Lotvall JO (2007) Exosome-mediated transfer of mRNAs and microRNAs is a novel mechanism of genetic exchange between cells. Nat Cell Biol 9 6: 654-659.

Valeri N, Gasparini P, Fabbri M, Braconi C, Veronese A, Lovat F, Adair B, Vannini I, Fanini F, Bottoni A, Costinean S, Sandhu SK, Nuovo GJ, Alder H, Gafa R, Calore F, Ferracin M, Lanza G, Volinia S, Negrini M, McIlhatton MA, Amadori D, Fishel R, Croce CM (2010) Modulation of mismatch repair and genomic stability by miR-155. Proc Natl Acad Sci USA 107(15): 6982-6987.

Wang M, Zhang P, Li Y, Liu G, Zhou B, Zhan L, Zhou Z, Sun X (2012) The quantitative analysis by stem-loop real-time PCR revealed the microRNA-34a, microRNA-155 and microRNA-200c overexpression in human colorectal cancer. Med Oncol 29(5): 3113-3118.

Wang YX, Zhang XY, Zhang BF, Yang CQ, Chen XM, Gao HJ (2010) Initial study of microRNA expression profiles of colonic cancer without lymph node metastasis. J Dig Dis 11(1): 50-54.
Weissmann-Brenner A, Kushnir M, Lithwick Yanai G, Aharonov R, Gibori H, Purim O, Kundel Y, Morgenstern S, Halperin M, Niv Y, Brenner B (2012) Tumor microRNA-29a expression and the risk of recurrence in stage II colon cancer. Int J Oncol 40(6): 2097-2103.

Wittmann J, Jack HM (2010) Serum microRNAs as powerful cancer biomarkers. Biochimica et Biophysica Acta 1806(2): 200-207.

Xi Y, Formentini A, Chien M, Weir DB, Russo JJ, Ju J, Kornmann M (2006) Prognostic Values of microRNAs in Colorectal Cancer. Biomark Insights 2: $113-121$.

Zheng D, Haddadin S, Wang Y, Gu LQ, Perry MC, Freter CE, Wang MX (2011) Plasma microRNAs as novel biomarkers for early detection of lung cancer. Int J Clin Exp Pathol 4(6): 575-586.

Zomer A, Vendrig T, Hopmans ES, van Eijndhoven M, Middeldorp JM, Pegtel DM (2010) Exosomes: Fit to deliver small RNA. Commun Integr Biol 3(5): $447-450$.

This work is published under the standard license to publish agreement. After 12 months the work will become freely available and the license terms will switch to a Creative Commons AttributionNonCommercial-Share Alike 3.0 Unported License. 